\title{
DYDAKTYCZNY ASPEKT INTERPRETACJI WYNIKÓW WSKAŹNIKOWEJ ANALIZY DZIAŁALNOŚCI JEDNOSTEK GOSPODARCZYCH
}

\footnotetext{
Z a r y s t r e ś c i. Artykuł przypomina nauczającym, że interpretacje wyników analizy wskaźnikowej należy poprzedzać sprawdzeniem relacji licznika ułamka, jakim jest wskaźnik, z jego mianownikiem po to, aby przeprowadzona analiza była merytorycznie poprawna.

S ł o w a k l u c z o w e: analiza wskaźnikowa, związek licznika i mianownika ułamka.
}

Wspominamy dzisiaj nieodżałowanej pamięci profesora Zygmunta Zielińskiego, twórcę szkoły naukowej badań dynamiki procesów gospodarczospołecznych. Profesor dbał zawsze o to, aby interpretacja wyników zastosowania najróżniejszych metod analizy szeregów czasowych oddawała istotną treść tego, co się w badanym procesie ekonomicznym lub społecznym naprawdę zdarzyło. Poprzednie zdanie upoważnia mnie do zabrania głosu w sprawie wymienionej $\mathrm{w}$ tytule referatu.

Jestem obecnie pracownikiem Wyższej Szkoły Bankowej we Wrocławiu (nawiasem mówiąc - uważam tę uczelnię za najlepszą wśród wyższych uczelni prywatnych we Wrocławiu) i tam między innymi piszę często recenzje prac licencjackich i magisterskich, których tematyka dotyczy analizy wskaźnikowej. Zapoznawanie się z treścią tych prac skłoniła mnie właśnie do zajęcia się rzeczą nie nową, znana, ale jakby trochę zapomnianą - rzeczą dotyczącą interpretacji wyników analizy wskaźnikowej.

Stosowane powszechnie wskaźniki są, jak wiadomo, ułamkami. Zarówno w liczniku, jak i w mianowniku tych ułamków występują dwie różne kategorie ekonomiczne. Zwyczajnie analiza tych wskaźników polega wyłącznie na porównywaniu ich wartości w czasie, tj. aktualnie obliczony iloraz odnosi się do 
tego samego typu ilorazu z okresu poprzedniego i na tej podstawie ocenia, czy w badanym obiekcie nastapiła poprawa (sukces), czy też nic się nie zmieniło (stabilizacja), czy wreszcie mamy do czynienia z pogorszeniem sytuacji (porażka). Porównania obliczonych wskaźników mogą też dotyczyć obiektów przestrzennych, $\mathrm{tj}$. ustalenia np. rankingu przedsiębiorstw wybranej branży lub obiektów administracyjnych: państw gmin, powiatów województw lub grupy państw według obliczonych wskaźników. Czasami łączy się też w spojrzeniu na porównania wartości wskaźników aspekt przestrzenny z czasowym. Na ogół nie spotyka się jednak - przy tej okazji - głębszych rozważań, czemu należy przypisać sukces, stabilizację czy porażkę.

Warto zwrócić uwagę stosujących analizy wskaźnikowe, że podstawą głębszych interpretacji wyników przeprowadzanej analizy powinna być próba ustalenia prawidłowości w zależności licznika wskaźnika (ułamka) od jego mianownika, czyli próba budowy ekonometrycznego modelu dla licznika ułamka w zależności od jego mianownika. Poniżej podaję prosty, „szkolny” przykład, który - mam, nadzieję - wyjaśni omawiany problem.

Załóżmy, że interesują nas dwa wskaźniki: 1. koszt jednostkowy równy: koszty globalne mierzone wartościowo w złotówkach poniesione w okresie $t$ (symbol tej cechy to $Y_{t}$ ) podzielone przez wartość produkcji tego okresu (symbol tej cechy - to $X_{\mathrm{t}}$ ); 2 . wskaźnik zyskowności równy: zysk globalny w badanym okresie (symbol cechy to $Z_{t}$ ) podzielony przez wartość cechy $X_{t}$. Potrzebne dane przedstawia poniższa tabela.

Tabela 1. Przykładowe wskaźniki

\begin{tabular}{|c|c|c|c|c|c|}
\hline $\mathrm{t}$ & $\mathrm{X}_{\mathrm{t}}$ & $\mathrm{Y}_{\mathrm{t}}$ & $\mathrm{Z}_{\mathrm{t}}$ & $\mathrm{Y}_{\mathrm{t}} / \mathrm{X}_{\mathrm{t}}$ & $\mathrm{Z}_{\mathrm{t}} / \mathrm{X}_{\mathrm{t}}$ \\
\hline 1 & 20 & 15 & 5 & 0,750 & 0,250 \\
\hline 2 & 25 & 17,5 & 7,5 & 0,700 & 0,300 \\
\hline 3 & 36 & 22,5 & 12,5 & 0,643 & 0,357 \\
\hline 4 & 30 & 20 & 10 & 0,667 & 0,333 \\
\hline 5 & 40 & 25 & 15 & 0,625 & 0,375 \\
\hline 6 & 50 & 30 & 20 & 0,600 & 0,400 \\
\hline 7 & 45 & 27,5 & 17,5 & 0,611 & 0,389 \\
\hline
\end{tabular}

Źródło: obliczenia własne.

Patrząc tylko na dwie ostatnie kolumny tabeli zarejestrujemy w okresie 2 . W stosunku do okresu 1. - sukces, bo koszt jednostkowy zmalał, a zyskowność wzrosła. To samo powie się o okresie 3. w stosunku do okresu 2. Natomiast okres 4. w stosunku do okresu 3. wykazuje porażkę. Dalsze interpretacje wynikają z danych tabeli. Tymczasem, gdy ustalimy zależność cechy $Y_{t}$ od $X_{t}$ oraz $Z$ od $X_{t}$ w postaci modeli:

$$
Y_{t}=5+0,5 X_{t}
$$

oraz

$$
Z_{t}=-5+0,5 X_{t}
$$


to stwierdzimy, że w całym badanym siedmioelementowym okresie występuje zjawisko stabilizacji, co widać na poniższych wykresach. Zmienność wskaźników powoduje jedynie zmienność mianownika ułamka, czyli produkcji (cecha $X_{t}$ ). Jej zwiększenie powoduje zmniejszenie kosztu jednostkowego i równoczesne zwiększenie wskaźnika zyskowności, czyli w świetle wartości wskaźników - sukces, chociaż badany obiekt gospodarczy nie dołożył starań dotyczących „zduszania” kosztów. Sukces w postaci zwiększania produkcji jest zwykle w dużej części „zasługą” zwiększenia popytu ze strony świata zewnętrznego w stosunku do badanego obiektu.

Na wykresach 1 i 2 pokazano punkt o współrzędnych: $X=50, Y$ oraz $Z=25$. Punkty te dotyczą okresu $t=6$. W porównaniu z danymi z okresu $t=5$ (patrz tabela) daje to wskaźnik kosztu jednostkowego równy 0,25 , a wskaźnik zyskowności równy 0,75 . Mamy sukces i tym razem jest to powód do chwały dla badanego obiektu, zmniejszono bowiem koszty $\mathrm{w}$ stosunku do ustalonego modelu kosztów zwiększając równocześnie zysk w stosunku do modelu zysków

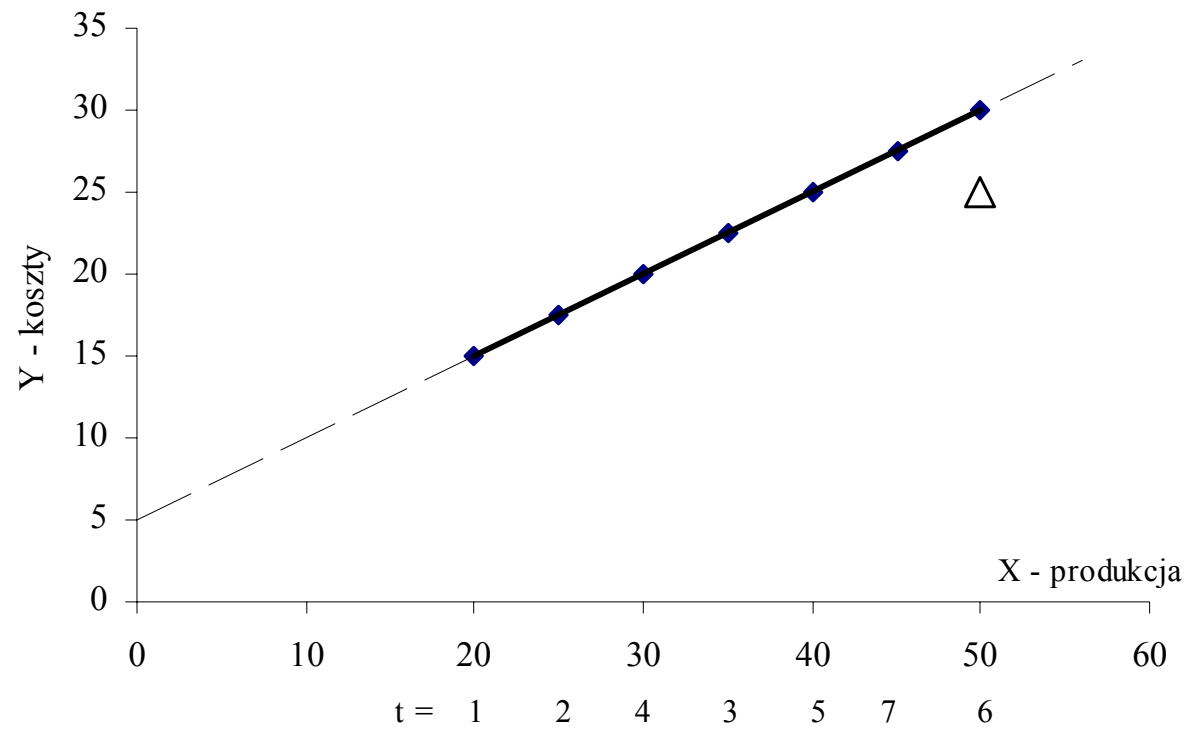

Wykres 1. Model kosztów

Źródło: opracowanie własne na podstawie tabeli 1. 


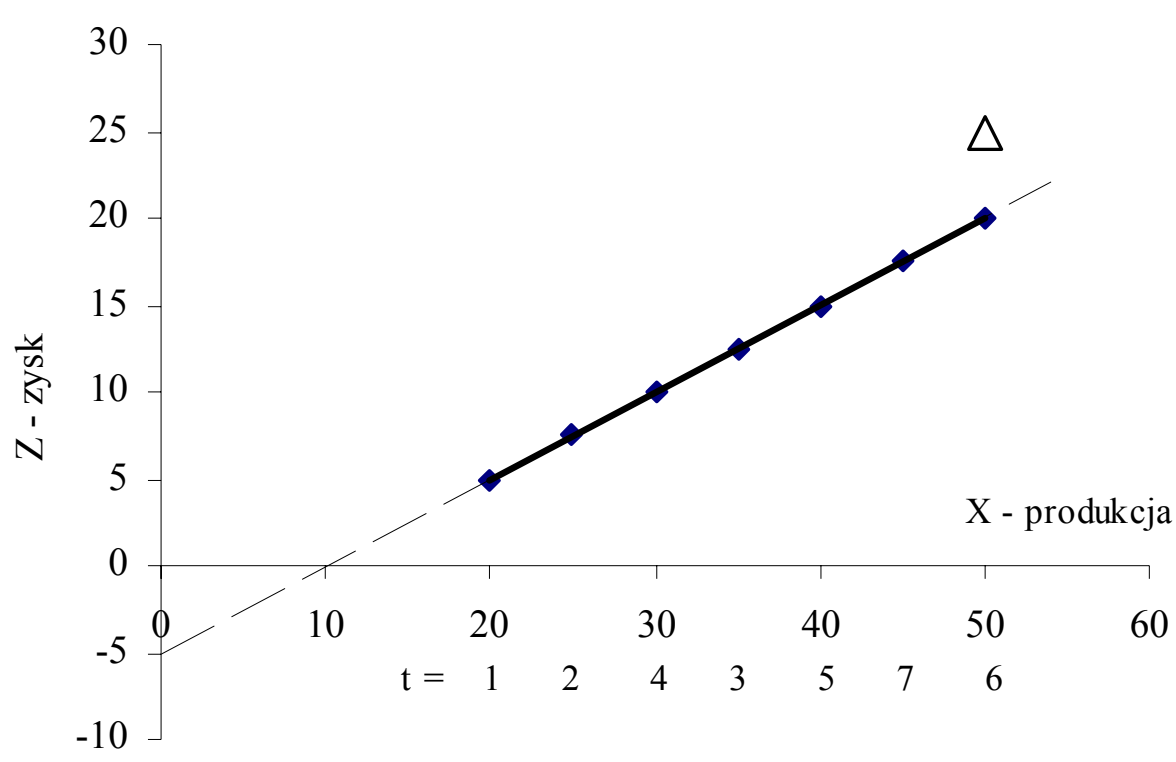

Wykres 2. Model zysków

Źródło: opracowanie własne na podstawie tabeli 1.

Oczywiście przykład jest wyidealizowany, w praktyce bowiem ustalane modele nie będą funkcjami dokładnie przechodzącymi przez rozrzut empirycznych punktów, będą występowały reszty i im będą one charakteryzowały się większym zróżnicowaniem tym ustaloną prawidłowość trzeba będzie opisywać - zamiast linią - przedziałem o szerokości zależnej od wspomnianego zróżnicowania reszt. Wtedy wszystkie wskaźniki mieszczące się w przedziale świadczą o stabilizacji, a tylko te, które wychodzą poza przedział mogą pokazywać sukces lub porażkę. To ostatnie zagadnienie daje nauczającym pole do wykazania swoich talentów dydaktycznych.

$\mathrm{Na}$ zakończenie wywodów jeszcze kilka zdań na temat wpływu stopnia zmienności cechy stanowiącej mianownik wskaźnika (ułamka) interpretację otrzymanych wyników liczbowych. Otóż dla ustalenia prawidłowości związku licznika ułamka i jego mianownika istnieje potrzeba, aby mianownik wykazywał dostateczną zmienność. Jednak jest ona w praktyce nie na tyle duża, żeby nawet w przypadku nieliniowego związku licznika z mianownikiem - nie można było z praktycznych względów zastapić nieliniowości związkiem wyrażonym linią prostą. Stąd w podanym przykładzie posługuję się wyznaczaniem regresji liniowej. Jeżeli natomiast zmienność mianownika wskaźnika jest znikoma, to potocznie obecnie stosowana analiza wskaźników nie budzi zastrzeżeń.

Uprzedzając dyskusję informuję, że zdaję sobie sprawę z często spotykanego faktu braku dostatecznej liczby danych dla ustalenia zależności między licz- 
nikiem, a mianownikiem wskaźnika. Tę trudność można dla niektórych wskaźników ominąć, Na przykład dotyczy to wskaźnika kosztu jednostkowego. Księgowi potrafią na podstawie swoich doświadczeń podać szacunek kosztów stałych (wyraz wolny w modelu uzależniającym koszty od produkcji $-a_{0}$ we wzorze (3)). Uzyskanie takiej informacji oraz zmodyfikowanie formuły budowy wskaźnika kosztu jednostkowego na następujący:

$$
\left(Y_{t}-a_{0}\right) / X_{t}
$$

pozwala na ocenę sukcesu, stabilizacji lub porażki przez porównanie dwóch wskaźników, bez zwracania uwagi na wartość produkcji (mianownika ułamka).

\section{TEACHING ASPECT OF THE INTERPRETATION OF INDEXES IN COMPANIES ACTIVITY ANALYSIS}

$\mathrm{A} \mathrm{b} \mathrm{s} \mathrm{tra} \mathrm{ct.} \mathrm{The} \mathrm{paper} \mathrm{remember} \mathrm{teaching} \mathrm{staff} \mathrm{that} \mathrm{the} \mathrm{interpretation} \mathrm{of} \mathrm{index} \mathrm{analysis} \mathrm{results}$ should be preceded by checking the relation between numerator and denominator to ensure the correct results with regard to the domain knowledge.

$\mathrm{K}$ e y w o r d s: index analysis, numerator and denominator relation. 
